\title{
İran'da Nasırüddin Şah ve Muzafferüddin Şah Dönemlerinde İngiltere ve Rusya'ya Verilen İmtiyazlar (1848-1906)
}

\author{
Privileges Granted to England and Russia in Nasırüddin Shah and \\ Muzafferüddin Shah Period in Iran (1848-1906) \\ Yilmaz KARADENİ*
}

\begin{abstract}
Öz
İran'ın Nasırüddin Şah ve Muzafferüddin Şah dönemlerinde İngiltere ve Rusya tarafından yarı sömürge durumuna getirilmesi süreci Kaçar idaresinin siyasi olarak yıpratılmasıyla birlikte başlamıştır. İngiltere, bu işin merkezinde olmuș, Rusya'yı ise kendi siyasi ve ekonomik menfaatleri doğrultusunda yönlendirmiștir. Rusya'nın İran'ın kuzeyinde askeri ve iktisadi nüfuz kurmasına ses çıkarmayarak veyahut aracı olarak, bu devletin güneydeki petrol bölgelerine sarkmasını önlemiştir. Nasırüddin Şah'ın idari olarak dışarıdan gelen hamleleri savuşturacak kabiliyette olmaması ve mali olarak İngiltere ve Rusya'ya yönelerek borçlanması, bu iki devletin İran'dan imtiyaz almada bağımsızlık sınırlarını zorlamalarına yol açmıştır. Muzafferüddin Şah'ın döneminde verilen imtiyazlar ile yerli üretim durma noktasına gelmiş, dışarıdan getirtilen iş̧̧iler üzerinden yapılan misyonerlik faaliyetleri iç dengeleri iyice bozmuştur. İngiliz ve Rus sermayedarlar tarafından alınan imtiyazlar ve İran'ın ağır borç yükü altına sokulması, iki devletin burada kurduğu bankalar üzerinden gerçekleşmiştir. Petrol ve madenlerin çıkartılması için alınan imtiyazların içerisine arkeolojik kazı yapma maddeleri de eklenerek Pers ve Sasani dönemi hazineleri ve eserleri talan edilmiştir. İran'dan kendi sanayilerine hammadde taşımak için alınan demiryolu ve telgraf hatları imtiyazları bütün İran topraklarının uzmanlarca taranmasına sebep olmuştur. İngiltere'nin kurduğu Bank-1 Şahinşahi ve Rusya'nın kurduğu Bank-1 İstikrazi aracılığıyla Kaçar hükümetinin borçlanması sağlanarak siyasi ve ekonomik nüfuz ile birlikte geri kalmışlık psikolojisi kabul ettirilmiştir.
\end{abstract}

Anahtar Kelimeler: İran, Kaçar Hanedanı, İngiltere, Rusya, Sermayedar, İmtiyaz.

\begin{abstract}
The process of turning Iran into a semi-colonial state by Britain and Russia in the Nasiruddin Shah and Muzafferuddin Shah periods started with the political destruction of the Qajar administration. Britain was at the center of this work, and it directed Russia towards its own political and economic interests. It has prevented Russia from dangling into the oil regions in the southern part of Russia, as a means of making its military and economic influence in the north of Iran. The fact that Nasiruddin Shah did not have the capacity to ward off internally disproportionate movements, and borrowed financially from England and Russia, led the two states to push the boundaries of independence in Iran from obtaining concessions. With the privileges given in Muzafferüddin Şah's period, domestic production came to a halt and the missionary activities carried out on the outsourced workers disrupted the internal balances. The privileges taken by the British and Russian capitalists and the heavy debt burden of Iran were carried out through the banks established by the two states. Archaeological excavation materials were added to the concessions taken for the extraction of oil and mines, and the treasures and works of Persia and Sassanid period were plundered. The privileges of rail and telegraph lines taken from Iran to transport raw materials to their industries have led to the screening of all Iranian lands by experts. Through the Bank-1 Şahinşahi founded by Britain and Bank-1 İstikrazi established by Russia, the Kashar government borrowed and adopted a psychology of backwardness along with political and economic influence.
\end{abstract} Key Words: Persia, Nasiruddin Shah, Muzafferüddin Shah, England, Russia, Magnates, Privileges.

\section{Giriş}

Muhammed Şah'ın oğlu ve Kaçar hanedanlığının dördüncü şahı olan Nasırüddin Mirza, Tebriz'de on altı yaşına kadar hocası Mirza Taki Han'ın eğitiminden geçmiştir. Babasının 1848'de ölmesinden sonra on sekiz yaşında Tehran'a getirtilerek "Nasırüddin Şah" unvanıyla tahta oturtulmuştur (Kadıyani, 1376: 724). Nası̈üddin Şah'ın tahta geçmesinde büyük pay sahibi olan hocası Mirza Taki Han ise "Emir-i Kebir" unvanıyla sadrazamlığa getirilmiştir. Tahta oturmasından sonra "sultan-ı sahibkaran" veya katledilmesinden dolayı "şah-l şehit" olarak anılmıştır (Ademiyet 1362: 29).

\section{* Doç. Dr. Amasya Üniversitesi, Fen-Edebiyat Fakültesi, Tarih Bölümü, yilmazkaradeniz44@ hotmail.com}

Karadeniz, Y., (2019). İran'da Nasırüddin Şah ve Muzafferüddin Şah Dönemlerinde İngiltere ve Rusya'ya Verilen İmtiyazlar (1848-1906), Asia Minor Studies, Cilt, 7 Say1 2, 231-243, Gönderim tarihi: 07-05-2019, Kabul tarihi: 25-07-2019.

Araştırma Makalesi. 
Nasırüddin Şah, yaklaşık elli yıl süren saltanatı sırasında ülke idaresinin aksayan yönlerini 1slah etmeye çalışmıştır. Ancak kendi hocası ve sadrazamı Emir-i Kebir başta olmak üzere etrafındaki iyi niyetli ve tecrübeli devlet adamlarının fikirlerine itibar etmeyerek dalkavuklara itibar etmiştir. Bulundukları mevkilerini kaybetmek istemeyen ve birbirleriyle mücadele halinde olan bazı saray görevlileri dalkavukluğu tercih ederken, yapılacak 1slahatların mesuliyetini taşımak istemeyenler ise şahın her şeyin en iyisini yapacağını telkin ederek hata yapmasına sebep olmuşlardır (Nasır, 1363: 256). İran'da gittikçe artan İngiliz ve Rus nüfuzu, şahın sağlıklı bir şekilde ıslahat yapmasını engellemiş, iki devletin nüfuzunda kalarak verdiği sınırsız imtiyazlar ekonomik ve siyasi buhranlara sebep olmuştur. Bazı devlet adamlarının adı geçen devletler adına çalışarak onlardan rüşvet almaları, imtiyazların sınırlarını zorlamış ve ülkenin yarı sömürge haline gelmesine sebep olmuştur (Sipihr, 1353: 146-148).

Nasırüddin Şah döneminde (1848-1896) İran'ın yarı sömürge haline getirilmesi, safhalar şeklinde gerçekleşmiştir. Birinci safhada, askeri sslahatlar için İngiltere ve Fransa'ya gönderilen devlet adamları mason locaları vasıtasıyla elde edilmiş ve asli gayelerinden uzaklaşmaları sağlanarak dönüşlerinde zararlı unsurlar haline gelmişlerdir. İran'a dönüşlerinde ise kendi ülkelerinin menfaatleri yerine İngilizlerin İran'daki menfaat bekçiliğini yaparak siyasi idarelerinin yıpratılmasında görev almışlardır. İkinci safhada İran'ın borç para almaya mecbur ettirilmesinden sonra yeraltı ve yerüstü kaynaklarının teminat ve imtiyaz olarak alınması gerçekleşmiştir. İngiliz sermayedarlar Rueter ve Talbot'a bütün kaynakların imtiyaz olarak peşkeş çekilmesinden sonra ekonomik olarak zor günler geçiren halk, açlıkla karşı karşıya bırakıldığı gibi yerli üretim durma sınırına gelmiştir. Üçüncü safhada ise bütün millî kaynakları sömürülmeye başlanan halka, istibdat yönetiminden dem vurularak özgürlük ve meşrutiyet rejimi ilaç olarak sunulmuştur. Melkum Han, Ebul Kasım Han, Mirza Ağa Han Nuri ve Cemaleddin Esedabadi gibi birçok kişi meşrutiyet isteklerine yardımcı olunca idarenin tamamı İngilizlerin eline geçmiştir.

İran'1 on dokuzuncu asrın başlarından itibaren sömürge haline getirmek için harekete geçen İngiltere ve Rusya, buradaki menfaatlerinin ve siyasi emellerinin genişleyebileceği coğrafi, stratejik ve ekonomik bölgelerde nüfuz mücadelesine girişmişlerdir. Rusya, İran'ın kuzeyindeki bölgelerde, İngiltere ise petrolün bulunduğu güney bölgeleri ile Afganistan ve Belucistan sınırlarında nüfuz tesis etmişlerdir (Grothe, 1369: 264). İki devlet, 1907'deki müzakerelerden sonra birbirilerine karşı aldatıcı güzel cümlelerden kurulu ve sözde İran'ın bağımsızlığını, gerçekte ise taksimini içeren anlaşmayı imzalamışlardır (Karadeniz, 2017: 225). İngiltere'nin bu anlaşmayı istemesinde Almanya'nın rakip olarak sahneye çıkması ve doğuda nüfuzunun yayılacağı endişesi etkili olmuştur (Keddie, 1381: 72). Nasırüddin Şah'ın 1873'teki Avrupa seyahati sırasında İran ile Almanya arasında bir ticaret anlaşması imzalamasından sonra siyasi ilişkilerin artması, 1883'teki Avrupa seyahatinde ise Bismark ile gizli görüşme yapması, İngiltere'nin dikkatinden kaçmamıştır (Karadeniz, 2017: 225). Şah'ın seyahatinin Paris kısmında III. Napolyon ile imzalanan bir anlaşma ile Şuş bölgesinde Fransız arkeolog Marcel Auguste Dieulafoy'a kazı yapma izninin verilmesi, İran'da menfaat peşinde olan İngiltere'yi iyice telaşlandırmıştır (Karadeniz, 2006: 233). Fransa ve Almanya'nın İran ile ilgili siyasi ve ekonomik hamleleri karşısında devreye giren hileli İngiliz diplomasisi, Fransa'yı bertaraf ettikten sonra Rusya'yı kontrol altında tutmuş, bu devletin İstanbul Boğazı ve Fars Körfezi'ne doğru sarkmasını engellemiştir. İngiltere, bunun için Rusya'yı bazen yanında tutarak bazen de karşısına alarak bu devletin siyasi ve askerî manevra alanını daraltmıştır. Ancak Almanya'nın doğuya yönelip Berlin-Bağdat Demiryolları projesine el atması ve Fars Körfezi ticari havzasına göz dikmesi, İngiltere'nin siyaset değişikliğine gitmesine sebep olmuştur (Kazımzade, 1354: 56). İngiltere, bundan böyle İran üzerinde kurmuş olduğu nüfuza ekonomik sömürüyü de ekleyerek daha fazla beklememe kararı almıştır 
(Mohdevi, 1379: 282). 1872-1892 yılları arasında İran'ın bütün millî kaynaklarını imtiyaz olarak almıştır (Keddie, 1381: 72-74). Kuzeyde kontrol altında tuttuğu Rusya'nın Hindistan'ın önündeki Sağlık Kemeri'ne yani Afganistan'dan Fars Körfezi'ne kadar olan bölgeye fazla yaklaşmadan İran'ın kuzeyinde ekonomik imtiyazlar elde etmesine ses çıkarmamıştır (Karadeniz, 2012: 329). ${ }^{1}$

İngiltere, İran'ın yarı sömürge durumuna düşürülmesinde mihver devlet olmuş ve bu iş için öncelikle siyasi zemin hazırlamaya koyulmuştur. Siyasi iktidarın yıpratılması ve taviz vermeye zorlanması için güneyden işgallere girişmiştir. Devlet mekanizmasının işleyişine müdahale ederek iç karışıklık ve mezhebi isyanlara sebep olmuştur (Hurmuci, 1363: 213). Bu aşamalardan sonra ekonomik imtiyazların koparılacağı siyasi havza oluşturulmaya başlanmıştır. Kaçar idaresinin başvuracağı alternatif kapıları kapatarak kendisine mahkûm ettirmiştir. Zengin petrol ve maden kaynakları ile Fransız arkeologlardan geriye kalan eski medeniyet kalıntılarını barındıran İran, İngiltere'nin ikinci aşama olarak düşündüğü iktisadi havza oluşturma siyasetiyle karşı karşıya kalmıştır. ${ }^{2}$ İngiltere'den geri kalmak istemeyen Rusya, İran'ın orta bölgesine kadar olan alanda ekonomik imtiyaz yarışına girmiştir. Her iki devlet, siyasi idarenin kendilerine tabi olması ve imtiyazlara ses çıkarmaması için bütün imkânları seferber etmişlerdir (Karadeniz, 2017: 227-229).

Kaçar hükümeti, İngiltere ve Rusya'nın İran'daki siyasi ve iktisadi nüfuz girişimlerini bertaraf edememiştir. 1797'de Feth Ali Şah'ın tahta oturmasından sonra İngiltere, Fransa ve Rusya ile imzalanan anlaşmalarda devletin bağımsızlık sınırları zorlanmıştır (Eşref, 1359: 46). İngiltere, 1828 'deki İran-Rus Savaşları sonunda imzalanan Türkmençay Antlaşması ile Rusya'nın Kafkaslardaki İran topraklarıyla iktifa etmesini sağlamıştır (Markham, 1364: 48). Ayrıca İran'ın savaş tazminatına mahkûm edilmesine aracı olmuştur (Karadeniz, 2012: 278285). Çünkü Rusya'nın Orta Asya üzerinden Hindistan'a yönelmesini kendisi için daha tehlikeli görmüş ve bu yüzden kendi nüfuzundaki İran'ın bir kısım topraklarının işgaline ses çıkarmamıştır. İran'ın Rusya'ya vereceği savaş tazminatını temin edememesiyle kendisinden borç almaya mecbur olacağını hesaplamıştır. İngiltere, 1857'deki Paris Anlaşmasıyla İran'ın Afganistan hâkimiyetini sona erdirdikten sonra buraya yerleşmiş, böylece Rusya ile Hindistan arasındaki güvenlik duvarını sağlama almıştır (Rahimzade, 1308: 106). Yukarıda adı geçen iki anlaşma sadece Kafkaslar ve Afganistan'ı İran'dan ayırmakla kalmamış, güney ve kuzeyden iktisadi nüfuz kapılarını açmıştır. Bundan sonra her iki devletin İran'dan aldıkları ticari imtiyaz ve gümrük indirimleri diğer batılı devletler tarafından da istenmiştir (Entner, 1352:4).

İngiltere, İran'1n zengin hammadde kaynakları ve petrolünün diğer batılı devletlerin iştahını kabarttığının farkında olarak hareket etmiştir. Rusya dışında hiçbir devletin buraya nüfuz etmesine fursat vermemiştir. Rusya'yı güneydeki petrol bölgeleri ve Fars Körfezi'nden uzak tutmak için kuzeyde nüfuz kurmasına ses çıkarmamıştır. Rus şirketleri kuzeyde, İngiliz şirketleri ise güneyde, arkalarına siyasi iktidarlarının desteklerini alarak İran'da imtiyaz avcılığına girişmişlerdir (Karadeniz, 2012: 391-396). İki devlet, İran'ın bütün yeraltı ve

\footnotetext{
${ }^{1}$ Sağlık Kemeri, İngiltere'nin Hindistan'ın güvenliğini başlattığı ve kuzeyde Afganistan'1, güneyde İran ve Basra Körfezi'ni içine alan bir hat üzerinde tehlikenin durdurulması için oluşturduğu güvenlik çemberidir. Bu güvenlik çemberinin iki önemli geçidi olan Herat ve Basra Körfezi, İngiltere için hayati önem taşıyordu. Bugün de aynı hat üzerinde mücadeleler devam etmektedir. Bkz. Arnold Wilson, The Persian Golf, London 1928; William Franklin, Sefername-i William Franklin (terc. Muhsin Cavidan), Tehran 1358

${ }^{2}$ Feth Ali Şah döneminde Fransa ile 1807'de imzalanan Finkenstein Anlaşması'nı firsat olarak gören Fransız arkeolog De Morgan, Mısır'daki kazı çalışmalarını hemen durdurup bütün ekibiyle İran'a gelmiştir. Pers ve Sasani kalıntıları hakkında bilgi sahibi olan Fransız arkeolog, Napolyon'un anlaşma ile kendisine sunduğu fırsatı iyi değerlendirip kazılara hemen başlamıştır. İran'ın Pers ve Sasani dönemi medeniyet eserlerini ve hazinelerini kısa bir sürede çıkararak Fransa'ya taşımıştır. Çalınan bu eserler ile daha sonra Louvres müzesi oluşturulmuştur. Bkz. John De Morgan, Heyet-i Ilmi-i Fransa der Iran (terc. Kazım Vedii), Tebriz 1338; Muhammed Hasan Han, Salname-i Devlet-i Aliye-i İran, Tehran 1291
} 
yerüstü kaynaklarını sömürmekle kalmamış, teb'alarının haklarını koruma bahanesiyle İran'ın bağımsızlığını ortadan kaldırmışlardır. Rusya, çok geçmeden Kafkaslardaki Rus teb'ayı bahane ederek sürekli İran'1 tehdit etmiş ve bölgeyi işgal etmiştir (İssawi; 1971: 360). Bu işgali asayişi koruma (Pacifier le pays) bahanesiyle açıklamıştır (Grothe, 1369: 265).

Kaçar iktidarının İngiltere'nin nüfuzuna girmesinden sonra içte ekonomik zorluklar yaşanması ve millî kaynakların elden çıkması birbirine paralel gitmiştir. Siyasi nüfuzun tesisinden sonra harekete geçen İngiliz ve Rus tüccarların sırtlarını hükümetlerine dayayarak imtiyaz avcılığına başladıklarını yukarıda söylemiştik. İmtiyaz avcılığında tabiatın bahşettiği imkânlar ve siyasi yapının şartlarından kaynaklanan esaslar ile toplum üzerinde sömürgeciliği oturtmaya çalışmışlar, halkın psikolojik olarak durumu kabullenmesi için uğraşmışlardır (Karadeniz, 2017: 175-176). Kaçar idaresi böyle bir tehlikeyi milletinden uzak tutacak ve menfaatlerini muhafaza edecek mahareti gösteremeyince çok rahat davranmışlardır. İran'1 gelişen sanayilerine hammadde deposu olarak gören iki devlet, imtiyaz avcılığında birbirilerini sürekli takip edip askerî güç seçeneklerini tehdit olarak kullanmışlardır. Rusya, daha çok 1lımlı nüfuz etme yöntemini kullanmıştır (Karadeniz, 2017: 173). Ancak birinin güneyde istediği imtiyaza diğeri kuzeyde talip olmuş, bu şekilde İran'ın millî vasfi ortadan kaldırılmıştır (Eşref, 1359: 47).

\section{Nasırüddin Şah ve Muzefferüddin Şah Dönemlerinde İngiltere ve Rusya'ya Verilen Imtiyazlar}

Rusya, 1881'de yirmi yıllığına İran'ın kuzey ve kuzeydoğu telgraf hatlarını tesis etme imtiyazı ile işe başlamıştır. Bu imtiyazın içerisine hattın geçeceği güzergâhtaki madenlerin çıkarılması ve kazı yapılması şartını dâhil ettirerek uzmanlarının bütün bu sahayı taramalarını sağlamıştır Karadeniz, 2017: 176). 1888'de verilen ikinci imtiyaz ile Rus sermayedar Liazanov'a Mazenderan kıyılarında balıkçılık yapma hakkı verilmiş, sadece kıyılarda balık avlama ile ilgili olan bu imtiyaz, daha sonra Hazar kıyılarında kontrolün tamamen elden çıkmasına sebep olmuş ve 1906'daki meşrutiyet dönemine kadar süresi uzatılmıştır. 1890'da İran'da bir Rus bankasının kurulmasıyla ilgili alınan imtiyaz, Rusya'nın İran'daki nüfuzunu iyice arttırmıştır. Poliakov ve Rafaeliyevic tarafından alınan bu imtiyaz ile Tehran'da "Bank- $\iota$ Ístikrazi-i Rus" kurulmuştur (Lambton, 1375: 293). Rus Bank-1 İstikrazi kurulduktan kısa bir müddet sonra hükümete borç para vermeye başlamıştır. Poliakov, bu imtiyaz ile yetinmeyip bir yıl sonra İran'da Rus Taşımacılık Sigortası Şirketi'nin kurulması imtiyazını da almıştır (Nasir, 1363: 377).

Rusya, İran'ın kuzey bölgelerinde imtiyaz almada güneydeki İngiltere ile yarıș halinde olmuş, 1893-1895 tarihleri arasında birden fazla imtiyazı içeren anlaşmayı Nasırüddin Şah'a zorla kabul ettirmeyi başarmıştır. Rus Taşımacılık Sigortası Enzeli-Kazvin, Kazvin-Hemedan ve Kazvin-Tehran arası şose yolu yapım imtiyazını almıştır. Enzeli'deki tatlı su göllerinde balıkçılık ve benzeri faaliyetleri imtiyazın içerisine dâhil ettirmiştir. 1898'de Azerbaycan'da Karacadağ madenlerini çıkarma ve işletme hakkını alan Rus tüccarlardan Gerainov ve Inakiev, kurdukları maden şirketi vasıtasıyla bu madenleri işletmiştir (Eşref, 1359: 48).

Rusya, İran'da kurduğu Bank-1 İstikrazi üzerinden devlet adamı ve tüccara borç para verirken, diğer yandan da Rus şirketlerin aldıkları imtiyazları idare etmiştir. 1900'de Muzafferüddin Şah'a \% 5 ile verilen 22.000.000 ruble borçlanmayı, 1902'de verilen 10.000.000 ruble tutarındaki borç takip etmiştir. 1902'de Azerbaycan demiryolu ve şose yolları yapımı imtiyazı bu banka aracılığıyla alınmıştır. 1907'de Odessa-Fars Körfezi arasında yapılacak yol yapımı teşebbüsü ise sonuçsuz kalmıştır (Grothe, 1369: 270). Colfa-TebrizKazvin demiryolu hattı döşenmesi sırasında Rusya'dan İran'a gelen petrol, maden uzmanı ve arkeologlar bu güzergâh boyunca hazine ve tarihî eser çıkarmak için araştırma yapmışlardır (İssawi, 1971: 36). 1911'de "Nobel Kardeşler Şirketi," Badkûbe petrol boru hattını Enzeli'ye 
kadar döşeme imtiyazı aldıktan sonra aynı şekilde, yani güzergâh boyunca Sasani döneminden kalma eser ve hazineler için arkeolojik kazı yaptırmıştır. Şirket, önemli şehirlerden Enzeli, Reşt, Hemedan ve İsfahan'da açtığ 1 şubelerle İran'da petrol ürünleri tekelini ele geçirmiştir. Gümrüklerin 1912'de borçlara karşı teminat olarak gösterilmesiyle buradan gelen gelirlerin elden çıkmasına sebep olmuştur (Grothe, 1369: 268). 1913'te ise Bank-1 İstikrazi'ye verilen imtiyaz ile Colfa-Tebriz ve Sofiyan-Şerefhane demiryolu hatt1 tesisi, maden, petrol arama-çıkarma ve işletme hakk1 verilmiştir (Timuri, 1332: 237).

İran'ın kuzeyinde Rusya'nın aldığı imtiyazlardan daha ağır imtiyazlar güneyde İngilizlere verilmiştir. İngiltere'ye telgraf hattı tesisi alanında ilk imtiyazı Nasırüddin Şah vermiştir (Ferahmend, 1387: 121). 1862'den 1868'e kadar çıkarılan beş kararname ile TehranHankin, Tehran-Buşir, Tehran-Belucistan, Tehran-Tebriz-Culfa telgraf hattının tesisi imtiyazı İngiliz şirketlere verilmiştir (Curzon, 1349: 615). İngiltere, telgraf hatları tesisi ile sadece Hindistan ve Fars Körfezi ile irtibatı sağlamak istememiş, bu hatların geçeceği bütün alanları petrol, maden, eski medeniyete ait hazine ve tarihî eserleri taramak istemiştir. "Doğu HindAvrupa Kumpanyası" aracılığıyla alınan bu imtiyaz ile İran'ın Tehran'dan itibaren güney ve doğusu tamamıyla taranmıştır (Mohdevi, 1379: 311).

Nasırüddin Şah zamanında İngiliz sermayedarlara verilen en önemli imtiyaz Yahudi asıllı Baron Julius Reuter'e İran'da “Bank-ı Şahinşahi”nin kurulması hakkının verilmesi olmuştur (Karadeniz, 2017: 178). ${ }^{3} 1889$ 'da verilen imtiyaz ile sınırlar zorlanmış ve devletin bağımsızlığ bir sermayedara peşkeş çekilmiştir (Ferahmend, 1387: 122-123). Reuter'e maden çıkarma, demiryolu, şose yolu yapımı ve paranın darbedilmesi hakkının verilmesi bütün iç pazarların ve para üzerindeki kontrolün elden çıkmasına sebep olmuştur (Devletabadi, 1330: 313). Bu banka aracılığıyla kurulan “The Persian Mining Corporation," Kaşem Adası'nda petrol aramaya başlamıştır (Fatih, 1335: 251). Bu imtiyaz ile yetinmeyen Nasırüddin Şah, 1888-1898 yılları arasında imzaladığ 1 beş anlaşma ile imtiyaz vermeye devam etmiştir (Karadeniz, 2017: 178). Tehran-Ahvaz, Burucerd-İsfahan, Tehran-Kum-İsfahan demiryolu hatları tesisi Bank-1 Şahinşahi'ye verilmiştir (Grothe, 1369: 277). 1841'de Bağdat'ta kurulan "Lynch Brothers Taşımacılık Şirketi (Safai, 1352: 146)," 1888'de aldığı imtiyaz ile Karun Nehri üzerinde gemicilik işletmesini başlatmıştır (Ferahmend, 1387: 123-124). Lynch Kardeşler Şirketi, 1898'da Ahvaz ile İsfahan arasında 270 mil (434 km.) uzunluğunda demiryolu yapmış, 1960'a kadar İran'da faaliyetlerine devam etmiştir (Karadeniz, 2017: 178). 1913 'te “Íngiliz Demiryolu Sendikası” na şose yolu yapımı imtiyazı verilmiştir (Eşref, 1359: $50)$.

Nasırüddin Şah'ın 1890'da İngiliz tüccar Gerald Talbut'a verdiği tütün imtiyazı, İran'1 siyasi, sosyal ve dinî çalkantıların içerisine sürüklemiştir (Ferahmend, 1387: 126). Bu anlaşma ile İran tütünlerinin ekimi, hasadı ve satın alınması hakkı halkın elinden alınarak bu şirkete peşkeş çekilmiştir. Şah'ın cömertçe verdiği bu imtiyazı kendi ekonomik çıkarına aykırı bulan Rusya, halkın imtiyaza karșı direnişinin yanında yer alarak daha sonra iptalini sağlamıştır (Karadeniz, 2017: 179). Anlaşma maddeleri arasına tazminatı sıkıştıran Talbut, anlaşmanın iptal edilmesiyle hiçbir kuruş ödeme yapmadan para kazanmış, tazminatı vermek zorunda kalan hükümet ise para temin etmek için İngilizlerin Tehran'daki tefecisi Bank-1 Şahinşahi'den borçlanmaya gitmiştir (Fevrier, 1368: 220).

\footnotetext{
${ }^{3}$ Osmanlı Devleti de 1856 'da İngilizler tarafından kurulan “Bank-ı Osmani” üzerinden yüklü miktarda borç altına sokulmuş, borç faizlerinin birikmesiyle geri ödeneme yapılamamış, İngiltere başta olmak üzere borcu veren devletler, Duyun-1 Umumiye idaresi kurarak siyasi bağımsızlı̆̆ı zedelemişlerdir. Bkz. Birgül Ayman Güler, "Yönetimde Özerklik Sorunu: Duyun-1 Umumiye Meclisi İdaresi 1881-1948," Memleket SiyasetYönetim Dergisi, Mayıs 2006, s. 97-119
} 
Muzafferüddin Şah, 1901'de D'Arcy'nin temsilcisi Alfred Mariot ile yaptı̆̆1 görüşmeden sonra bu sermayedara ilk petrol imtiyazını vermiştir. D’Arcy, aldığ 1 petrol çıkarma imtiyazı ile Azerbaycan, Gilan, Mazenderan, Horasan ve Esterabad haricindeki bütün kuzey bölgelerinde altmış yıllığına petrol çıkarma hakkını elde etmiştir (Karadeniz, 2017: 179). İngiltere'nin 1907'de Rusya ile anlaşmasının bir amacı da bu imtiyazı güvence altına almak istemesiydi. İngiltere, Rusya'nın Tehran dâhil ortadaki tampon bölgeyi aşarak güneydeki petrol bölgelerine sarkabileceğini ve işgal ettiği Tebriz'den çıkmayacağını düşünmüştür (Grothe, 1369: 272). Bunun için aceleyle "Consession Syndicate" şirketi aracılığıyla çıkarılan petrol çıkarma işi, 1909'da "Anglo Persian Oil Company” şirketi uhdesine verilmiştir (Karadeniz, 2017: 179).

İngiltere ve Rusya, İran'dan imtiyazları aldıktan sonra kendi tüccarları vasıtasıyla iç pazarları da ele geçirmişlerdir (Hacı Seyyah, 1346: 21). Petrol ve maden arama, telgraf ve demiryolu hatları yapımını alan sermayedarlar, yanlarında teknik elemanlar ile birlikte coğrafyacı, arkeolog, misyoner, haritacı gibi görevliler getirmişlerdir. Bir kısmı maden ve petrol aramak için makineleri taşırken, bir kısmı iç pazarlar ve tarımda faaliyet göstermek için uğraşmışlardır. Konsolosluklarda görevlendirilen misyonerler ise dört bir yana dağılarak İran halkı ve özellikle gençler arasında nifak tohumları ekmeye başlamışlardır (Karadeniz, 2017: 179).

İngiliz sermayedarlar İran'da petrol, bankacılık ve yeraltı kaynakları üzerinde yoğunlaşırken, Rusya daha önce mal mübadelesi yaptığı İran'ın kuzeyinde ticaret ve sanayi ile ilgilenmiş, bu yönde sömürmeye başlamıştır. Rusların himayesindeki Yunanlı tacirler Tebriz'de etkili olmuşlardır (Hüseyni Şirazi, 1312: 504). Rusya, İran'a gönderdiği tüccarların başına birer "Tacirbaşı" tayin ederek ve kuzey şehirlerinde konsolosluklar açarak ticari nüfuzunu arttırmıştır (Picot, 1897: 72). Tacirbaşılar, nüfuzlu ve etkili kişilerden seçildiği gibi İranlılar arasında da Rus tabiiyetini kabul eden İranlı tüccarlardan seçilenler de olmuştur (Fahrai, 1352: 214). Mesela Meşhed'de tüccar olan Feth Ali, Rusya'nın isteği ile bu göreve getirilmiş (Nikitine, 1326: 112), seçilenler meşrutiyet hareketi sırasında Rus menfaatleri yararına çalışmışlardır (Browne, 1351: 187). Tebriz ve kuzeydeki diğer şehirlerde yaşayan Ermeni tüccarlar da Rusya için çalışmışlardır (Ruşen, 1352: 145).

İran'ın İngiltere ve Rusya tarafından yarı sömürge durumuna düşürülmesi faaliyetleri Birinci Dünya Savaşı öncesinde kendisini iyice hissettirmiştir. Rus tüccarlarından Severian Kossych, cam kristal ve çini ticaretini tamamıyla kendi tekeline almıştır. Rus nakliyat şirketi hızlı bir şekilde gelişerek Astara, Bender-i Gez, Culfa, Reşt ve Tehran'da şubeler açmıştır. "Kafkas Merküri Gemicilik Şirketi," Enzeli'de bir şube açarak deniz taşımacılığına başlamış, Arzamanov'un Tehran ve Hemedan'da kurduğu şirket kuru meyve, zamk ve deri ticaretini elinde bulundurmuştur. Bu şirketin ylllık geliri 600.000 rubleyi bulmuştur. Stuken isimli tacir Meşhed ve Sebzevar'da faaliyet gösterirken, Rubenek'in İran pazarlarında sattığı çiçekli basma kumaşlar yıllık 5.300 balyayı bulmuş, bu satıştan yıllık 1.000 .000 ruble para kazanmıştır. Rus tüccarlarının şeker, kuru meyve ve dericilikten yıllık kazançları toplam 800.000 rubleyi geçmiştir (Cemalzâde, 1335: 16). "Russia Sigortacıllk" ve dokuma ile uğraşan "Prokhorov" şirketleri pazarlarda önemli bir yer tutmuştur. "Rosenblum" isimli şirket, Tehran'da pamuk ticareti ile uğraşırken, "Provodnik" şirketi galoş üretimini elinde bulundurmuştur. Galoş üretiminden yıllık 90.000 ruble gelir elde etmiştir I. Dünya Savaş1 öncesinde Rusların İran'da yıllık gelirlerinin toplamı 173.000.000 rubleyi bulmuştur (Eşref, 1359: 360).

İngiliz tüccar ve sermayedarlar, Birinci Dünya Savaşı öncesinde güneydeki şehir ve limanlardaki ticareti tamamıyla ellerine geçirmişlerdir. Doğu Hind Kumpanyası aracılığıyla Fars Körfezi kıyılarına getirilen Hindistan ve Uzakdoğu malları buradan içerilere ve Suriye 
limanlarına taşınmıştır. Trabzon ve İstanbul üzerinden getirilen mallar ise Tebriz pazarlarına sürülmüştür. Tebriz, çok kısa bir süre içerisinde İngiliz tüccarların yoğun olduğu bir şehir haline gelmiştir (Merağayi, 1344: 163). "Burgess Kardeşler Şirketi,” Abbas Mirza zamanında Tebriz'de kurulmuştu ve Trabzon üzerinden getirdiği malları İran'ın iç pazarlarına sürmüştü (Stuart, 1854: 225). "Mills and Co" şirketi, 1848'de 100.000 kadar tüfeği İran'a getirip Rus silah tüccarlarıyla rekabet etmiştir. Bu şirket, İsfahan ve Şiraz'da şubeler açarak silah satış işini genişletmiştir. Bağdat'da Alexander Hector, aynı şekilde silah ticaretiyle uğraşmıştır (Wright, 1361: 97). "Ralli and Angelasto" şirketi Tebriz'deki kumaş ticaretini tekelinde bulundurmuş, Manchaster'de üretilen kumaşları getirerek piyasaya sürmüş ve bu şekilde yerli üretimi zayıflatmıştır. Kendi ucuz ve kalitesiz kumaşlarını piyasada satıp karşılığında Gilan'ın kıymetli ipeklilerini alarak dışarıya ihraç etmişstir (Wright, 1361: 98).

Fars Körfezi'ndeki ticareti kontrolünde tutan "Hotz and Son," İngiltere himayesinde Hollandalılar tarafından kurulmuş bir şirket olup merkezi Londra'da idi (Şirazi, 1312: 539). "Ziegler and Co" ise İsviçre asıllı İngilizlerin kurduğu bir şirket olup, 1850'de Tebriz'i üs yaparak kumaş, gümüş ve halı ticareti yapmıştır (Wright, 1361: 99). İngiltere'nin Fars Körfezi'ndeki üçüncü önemli şirketi olan "Messrs. Muir, Tweedy and Co," daha sonra "Persian Gulf Trading Company" ismiyle faaliyetlerine devam etmiştir. 1866'da Buşir'de kurulan "Gray-Paul and Co," gemi taşımacılığ 1 yapmıştır. Londra'daki "British India Navigatıon Co" şirketine bağlı olarak 1871 'de Karun Nehri gemi işletmeciliğini yapmaya başlamıştır (Wright, 1361: 100). 1875'te Tebriz'de kurulan “Hild. B. Stevens and Son," 1934 yılına kadar Tebriz'de ticarete devam etmiştir. "Sason and Co" şirketi ise Buşir ve İsfahan'da daha çok afyon ticareti ile uğraşmıştır (Curzon, 1349: 573).

İngiltere'nin Hindistan hükümeti görevlisi John Malcom'un İran'ın güneyinde kendi adıyla kurduğu şirket, General Percy Sykes'ın kurduğu şirket gibi ticaret ile uğraşmıştır. Aynı şekilde Dixon'un şirketi güneydeki kıyılarda ticaret yapmıştır. Londra ve Meşhed'de faaliyet gösteren Forbes, Muhammere'deki Scott, Londra ve Tehran'da faaliyet gösteren Hoods, İngilizlerin Fars Körfezi'ndeki diğer şirketlerini oluşturmuştur. Schumann kardeşlerin Urumiye' deki şirketi ise Tebriz'de ticaretle uğraşmıştır (Issawi, 1971: 359).

İngiltere himayesinde İran'da kurulan şirketler, yerli zengin tüccarları kendi yanlarına çekerek onlardan istifade etmişlerdir. Bir kısmını kendisine ortak yaparak muhtemel tepkiyi önlemek istemişlerdir. Bir kısmını ise kendilerinin İran'da bulunmadığı zamanlarda ticari işleri yürütmeleri için yerli tüccarları ortak yapmışlardır. Bu dönemde İran'da İngiltere yararına çalışanların sayısı 50.000'i bulmuştur Ağa Muhammed İsfahani isimli zengin tüccar, Sason and Co şirketine ortak olmuştur. Meşhed'de Ali Ekber isimli İranlı tüccar, Ziegler şirketinin temsilcisi olmuştur (Grothe, 1369: 273-274). Yerli tüccarların bu şekilde ortaklıklarından istifade edilerek İran ipek halılarının halk tarafından dokunması sağlanmış, dışarıya götürülen bu halılardan yüksek karlar elde edilmitir (Wright, 1361: 99).

İran halısının dış piyasalarda çok tutulması İngiliz tüccarların bu alana yönelmelerine sebep olmuştur. Sultanabad'da kurulan üç şirket, tezgâhlarda kadın ve çocuklara dokuttuğu halıların hepsini ihraç etmiştir. 1870'de toplam halı dokuma sayısı 3.000'i geçmiştir. Ziegler şirketi, halı dokuma işine girerek Avrupa ve Amerika pazarlarına halı ihraç etmiştir (Dihgan, 1330: 164). 1880'de Ziegler şirketi ile rekabet etmek ve halı pazarına girmek için "The Persian Carpet" isimli şirket kurulmuştur. Şirket, yerli ev tezgâhlarında kadın ve çocuklara dokuttuğu halıları dışarıda yüksek fiyatlarla pazarlamıştır. 1906'da bir araya gelen İngiliz şirketleri, Hindli ortaklar da edinerek İran halı dokumasında müşterek çalışmışlardır (Vekili, 1354: 434).

İngiliz tüccarlar, Fars Körfezi'ndeki ticareti tekellerinde tutmak için Hintli tüccar ve ortaklara ihtiyaç duyuyorlardı. Çünkü İranlı ve Hintlilerin geçmişten gelen tarihî ve kültürel 
bağları aralarındaki ilişkilere de yansıyordu. İngilizler, bu iki milletin yakınlıklarından faydalanıyordu. Bunun için İran'daki İngiliz konsolosları bu iş ile görevli kılınmış ve İran tüccarlarından hatırı sayılır miktarda tüccar, İngiliz tabiiyetine girmiştir. Bu şekilde İngilizler körfez ticaretinde rakipsiz olmuşlardır. Mesela Buşir'in önemli tüccarlarından Hacı Baba isimli şahıs İngiliz tabiiyetine girmiştir (Bosworth, 1977: 331).

İngiltere'nin Rusya ile birlikte İran'1 yarı sömürge durumuna getirmesinde en etkili yöntemlerden birisi de burada kurulan bankalar aracılığıyla devletin ve yerli tüccarın borç altına sokulması olmuştur. İngiltere, Bank-1 Şahinşahi, Rusya ise Bank-1 İstikrazi aracılığıyla hem kendi tüccarlarının İran pazarlarını istila etmelerini sağlamışlar, hem de hükümet, devlet adamı ve tüccarlara borç para vermek suretiyle siyasi ve ekonomik tahakkümlerini kurmuşlardır (İbrahim Bey, 1355: 163). Sistemli olarak borçlandırılan hükümet, yetenekli ve basiretli devlet adamlarının olmayışından ağır borç yükü altına girmiş, borçlara karşılık teminat olarak gösterilen kaynakların elden çıkmasıyla istiklalin kaybolması kaçınılmaz hale gelmiştir (Eşref, 1359: 56). Curzon, 1892'de İran'da İngiliz bankası olarak kurulan Bank-1 Şahinşahi ile ilgili sözlerinde, İran parasının düzensizliğinden ve paranın taşınmasındaki sıkıntılardan bahsederek gerçek amacı gizlemiştir (Curzon, 1349: 613).

Nasırüddin Şah, Avrupa seyahati sırasında İngiltere'yi ziyaret ederken, İngiliz sermayedarların bir bankanın kurulması ile ilgili telkinlerine maalesef aldanarak inanmıştır. Bunun için 1863'te Mahmud Han ve Hasan Ali Han'1 Paris ve Londra'ya göndererek bankacılığı incelemelerini istemiştir. 1864'te Paris'teki kuyumcu Jean Savalan ile yapılan görüşmede, İran'da bir bankanın kurulması kararlaştırılmıştır. Savalan, 2.000.000 İngiliz lirası sermayeyi borç vereceğini taahhüt etmiştir (Timuri, 1381: 182). Adı geçen şahısların İran'a dönüşünden sonra "The New Oriental Banking Corporation" ismiyle bir banka kurulmuştur. Bankanın faaliyette bulunduğu iki yıl süresince İranlı sarraflar ile aralarında sıkıntılar olmuş, İngiltere tarafından Bank-1 Şahinşahi'nin kurulmasıyla bu banka kapanmıştır (Eşref, 1359: 58).

İngiltere tarafından İran'da Bank-1 Şahinşahi'nin kurulması, 1889'da Nasırüddin Şah ile İngiliz elçi Velf arasındaki görüşmelerde sadrazamın telkinleri sonucu kararlaştırılmıştır. Bankanın kurulması imtiyazı Yahudi asıllı İngiliz Baron Julius Reuter'e verilmiştir (Timuri, 1381: 108). Reuter, sadrazam nezdinde yaptığı girişimler ve verdiği rüşvetler ile isteklerine nail olmuş, hem bankanın kurulması, hem de 1872 'de daha önce aldıktan sonra iptal edilen petrol imtiyazlarına tekrar kavuşmuştur. İngiliz hükümetinin şah üzerindeki nüfuzu ve Rusya'nın da bu sırada İran'da bir banka kurma düşüncesinden dolayı karşı çıkmaması, Reuter'in işini kolaylaştırmıştır. Bu dönemde Avrupa seyahatleri kendisine cazip gelen Nasırüddin Şah, devletin kaynaklarının gitmesinden çok seyahat için alacağı borç parayı düşünmüştür. Nitekim bankanın kurulmasıyla birlikte 40.000 İngiliz lirası ve \% 6 faiz ile İran'a borç verilmiştir. Nasırüddin Şah, 1872'de Reuter'e verdiği ve daha sonra iptal etmek zorunda kaldığı imtiyaz tazminatının ödenmesi yolunu bu borçlanmada görmüştür. Ortada hiçbir sebep yok iken bütün İran petrol ve madenlerini imtiyaz olarak vermesi ve arkasından oluşan tepki sebebiyle iptal etmesi, anlaşmaya konulan tazminat maddesiyle Reuter'e durduğu yerde para kazandırmıştır. Reuter, yeni imtiyazın alınmasında bu tazminatı bir koz olarak kullanmış ve istediğini elde etmiştir (Eşref, 1359: 58).

İran'da bir bankanın kurulması imtiyazını alan Reuter, şartnamenin içerisine petrol ve maden aramayı dâhil ettirmiştir (Kazımzade, 1354: 190). Yıllardır beklediği firsatı bulan Reuter, petrol rezervi yüksek olan Abadan, Ahvaz, Buşir gibi şehirlerde çok sayıda banka şubesi açmıştır. Bankanın kuruluşundan kısa bir süre sonra para ve ticaret üzerinde hâkim olmuştur. Banka, İranlı zengin sarrafların esnaf ve tüccara borç vermelerini önleyerek kendilerine bağlı tüccarları desteklemeye başlamıştır. Bu durum İranlı tüccarın nefretine 
sebep olmuş, banka idarecilerinin Londra'ya gönderdikleri raporlara şöyle yansımıştır; "Iranlı tüccarlar Bank-ı Şahinşahi'den pek razı değildir. 4.000 hisseli ve her hissesi 25 tümen olacak bir banka kurmaya çallşlyorlar." Raporlarda, bankanın İran hükümetine verdiği borcun süresinin uzatılması gerektiği de bildirilmiştir (Karadeniz, 2017: 183).

İran'da İngiliz sermayeli Bank-1 Şahinşahi'nin kurulmasından bir yıl sonra Rusya devreye girerek kendisinin de banka kurmak istediğini İran hükümetine bildirmiştir. 1890'da Doulguruky tarafindan İran'a gönderilen Poliakov, Tehran'da Rusya'ya bağlı "BankÍstikrazi" ismiyle bir bankanın kurulması için hükümet ile görüşmelere başlamıştır. İki yıl süren görüşmelerden sonra 1892'de Bank-1 İstikrazi kurulmuştur (Eşref, 1359: 59). Yetmiş beş yıllığına alınan banka kurma imtiyazı, 1894'te resmen Rus bankası statüsüne alınmıştır (Timuri, 1381: 337). Bankanın merkez şubesi Tehran'da olup kuzey şehirlerinde de şubeler açılmıştır (Kazımzade, 1354: 255).

Bank-1 İstikrazi'nin faaliyetlerinin esası, devlet ricali ve hükümete borç para verme şeklinde olmuştur. Hükümet ağır borç yükümlülüğü altına sokulduktan sonra Rusya'ya taviz vermeye zorlanmıştır. Bu konuda; "Bankanın 30.000.000 menat (Rus parası) olan ilk sermayesinden 3.000.000'u kasasinda durmaktadır. Geriye kalan 27.000.000 ise tamamıyla devlet ricali ile ayana borç olarak verilmiştir." Demek suretiyle alınan borcun büyüklüğüne dikkat çekilmiştir (Cemalzade, 1335: 104). Bank-1 İstikrazi, bankacılığın dişında Rus tüccarının İran pazarında hâkim olması, taşımacılık ve sigortacılık işleri için de uğraşmıştır (Grothe, 1369: 268).

İran'da bankacılık petrol, maden, ulaşım ve telgraf hatları için kıyasıya mücadeleye girişen İngiliz ve Rus sermayedarlar, bununla yetinmeyip sanayi ve hammadde alanına girmişlerdir. Zengin hammadde kaynaklarının bulunduğu bölgelerde işletmeler kurarak yerli sanayinin gerilemesine sebep olmuşlardır. El tezgâhı ve küçük işletmelere dayanan yerli üretim bunlarla rekabet edemeyip gerilemiştir. Mesela Yunanlı tacir Seufilaktos, Rusya himayesinde 1890 'da Gilan zeytinlerinin imtiyazını Nasırüddin Şah'tan yirmi beş yıllığına almış, 1896' da fabrika kurmak suretiyle üretime başlamıştır (Timuri, 1381: 334). Fabrika için İngiltere'den satın alınan makineler gemilerle getirildikten sonra Gilan'da monte edilmiş, üretilen zeytinyağının tamamı Rusya'ya ihraç edilmiş, ancak daha sonra Rusya'nın gümrükleri yüksek tutmasıyla ihracat yapılamamış ve fabrika kapatılmıştır (Abdulayev, 1963: 131). 1891'de Sadrazam Eminüddevle'nin teşviki ile Poliakov tarafindan kibrit fabrikası kurulmuştur (Hidayet. 1333: 138). Levontin tarafından Tehran'da kurulan başka bir kibrit fabrikasında Yahudi kadın işçiler çalıştırılmıştır (Abdulayev, 1963: 129). 1896'da Belçikalı ve İranlı tüccarlar tarafından Tehran'da kurulan şeker fabrikası, dönemin en büyük binasına sahip olmuş, işçi maliyetlerinin düşük olmasından dolayı ucuz üretilen İran şekeri diş piyasaya sürülmüştür (Hidayet, 1333: 138).

İran'da pamuk üretiminin yaygın olarak yapıldığı bölgelere gelen Rus tüccarlar pamuk temizleme fabrikaları kurmuşlardır. 1902'de Adam Osser tarafindan üç tane, Sadık Aliyev tarafindan bir tane pamuk temizleme atölyesi kurulmuştur. 1904'te Bank-1 İstikrazi'nin teşvikiyle birçok yerde pamuk işleme fabrikaları açılmıştır. 1906 'da motor üretim fabrikaları kurularak üretilen motorlar pamuk işlenen fabrikalarda kullanılmıştır (Cemalzade, 1335: 95). Rus tüccarlar, 1889'da Gilan'dan başlamak üzere ağaç kesim ve orman ürünleri üretim ve pazarlanması işine de girerek İran'ın kuzey ormanlarını keserek orman ürünlerine dönüştürmüşlerdir. Daha sonra Urumiye ve Taleş ormanlarının kesimi imtiyazını alarak bu alanda büyük sermaye kazanmışlar ve yıllık gelirleri 130.000 rubleyi geçmiştir. Tomanev, Liazanov ve Hamid Beg Zülkadirov tarafından kurulan atölyelerde elde edilen ağaç ürünleri, gemi ve trenler ile ihraç edilmiştir (Nikitine, 1326: 101). Rusya'nın Reşt konsolosluk görevlisi Nikitine bu konuda şunları kaydetmiştir; "Hind tarzında binalar yapılmıştı. Geceleri 
bina elektrik lambalarının ışığına boğuluyordu. Taleş ormanlarından kesilen ăgaçların kolay işlenmesi için fabrika şirket binasının yanında yapılmıştı” (Nikitine, 1326: 105).

İran'da bat1 sermayesinin sömürmek istediği alanlardan bir diğerini de ipek dokumacılığı ticareti oluşturmaktaydı (Robino, 1350: 73). Muhammed Hasan Reşti, 1883'te Reşt'te Rus ortaklı bir fabrika kurmuş, çok kıymetli olan İran ipeklileri dışarıya ihraç edilmiştir (Eşref, 1359: 64). 1891'de Belçika Kumpanyası kristal fabrikası, 1900'da Muhammedov tarafından Meşhed'de sigara fabrikas1, 1913'te Ermeni asıllı Rus Gregorian tarafindan Kazvin'de un fabrikası kurulmuştur. Ruslar, ayrıca I. Dünya Savaşı sırasında İran'da alkol fabrikaları kurmuşlardır (Cemalzâde, 1335: 93). 1914'te Urumiye'de alkol fabrikası kuran Ruslar, halkın alkol tüketmesi için çaba sarf etmişlerdir (Abdulayev, 1963: 154).

Almanya, Birinci Dünya Savaşı öncesinde Fars Körfezi’ndeki İngiliz ticari üstünlüğünü kırmak için harekete geçmişse de başarılı olamamış ve İran'ın kuzeybatı taraflarına yönelmiştir. 1910'da Tebriz'de sadece bir montaj fabrikası kurabilmiş, ancak bu işte başarılı olamayınca halı dokuma işine girmiştir. Şehzade İmam Kuli Mirza, Urumiye Gölü'nde gemi işletmeciliği için Alman Shineuman ile ortaklık yapmıştır. Gerek ortaklık ve gerekse şahıs olarak kurulan işletmeler ile 1909'da Tebriz'deki Alman tüccar sayısı altmış civarına çıkmıştır. Meşrutiyetin ilanından sonra ve I. Dünya Savaşı sırasında İran'ın ekonomik istilası hızlanmış, siyasi ve ekonomik bağımsızlık elden çıkmıştır (Abdulayev, 1963: 151). İngiltere ve Rusya, Birinci Dünya Savaşı'nın başlarında İran'1 resmen yarı sömürge durumuna düşürmüşlerdir (Fatih, 1335: 66).

\section{Sonuç}

İngiltere ve Rusya, öncelikle Kaçar idaresi üzerinde siyasi ve askerî nüfuz kurduktan sonra imtiyaz koparmaya başlamışlardır. Her iki devlet, imtiyaz avcılığında şahın ve devlet adamlarının idari beceriksizliklerinden iyi istifade etmişlerdir. İmtiyaz şartnamelerinin kendilerine bahşettiği imkânları iyi kullanarak İran pazarına ucuz ve kalitesiz malları sürerek yerli üretimin durmasına, işsizliğin artmasına sebep olmuşlar, sanayilerine lazım olan hammaddeleri ülkelerine taşımışlardır. İki devlet, siyasi ve ekonomik olarak İran'ı ikiye bölüp petrol ve maden arama, orman ürünleri, demiryolları tesisi gibi büyük işlere üçüncü bir ülkeyi yanaştırmamış, İran'ı kendilerinin hayat kaynağı olarak görmüşlerdir. Sanayilerine lazım olan hammaddeyi, İran'da demiryolu ağı tesis ederek rahat ve ucuz taşımışlardır. Telgraf hatları tesisi ile sömürdükleri kaynakların güvenli bir şekilde taşınmasını sağlamışlardır. Demiryolu hattı imtiyazları içerisine maden aramayı katarak İran'ın bütün petrol bölgelerini tespit etmişlerdir. Çok geçmeden Rusya kuzeyde, İngiltere ise güneyde petrol ve maden aramayı tekeline almıştır. İngilizlerin hileli diplomasisi tarafından yönlendirilen bu siyasetin hedefinde, Rusya'nın İran'ın kuzeyi ile iktifa edip Fars Körfezi ve Osmanlı boğazlarına inmemesi yer almıştır.

İran'ın yarı sömürge haline getirilmesinde İran tüccarlarının mukavemeti olmamış, bir kısmı rüşvet ile elde edilirken, bir kısmı da İngiliz ve Rus tabiiyetine girerek onların İran'daki ticari temsilciliği ve menfaat bekçiliğini yapmışlardır. Aynı şekilde bazı devlet adamlarının da menfi rol oynadıkları, İngiltere ile birlikte kendi ülkelerinin kaynaklarını yabancı sermayedarlara peşkeş çektikleri görülmüştür. Osmanlıdaki ittihatçı ve meşrutiyetçilerle birlikte çalışan İran meşrutiyetçileri, bu pazarlıkların bir kısmını, üstlendikleri İstanbul'da yapmışlardır.

İngiltere, İran'da daha çok bankacilık, madenler ve petrol üzerinde durarak siyasi idareyi bu alanlarda imtiyaz vermeye zorlamıştır. Rusya da dâhil olmak üzere ikinci bir yabancı ülkenin güney ve orta bölgelerde imtiyaz almasına fırsat vermemiş, bu hususta sürekli 
idareyi tehdit altında tutmuştur. Böylece Hindistan'ın önündeki güvenlik şeridini emniyete aldığı gibi, gelecekte petrolün çıkarılması konusunda doğabilecek rakipleri de bertaraf etmiştir. Rusya ise petrolden ziyade kuzeyde ticaret ve sanayi ile uğraşmıştır. Bu şekilde İran'ın bütün iktisadi kaynakları ve ticari imkânları üzerinde denetim kurulmuş, yerli üretim yapılamaz duruma getirilmiş, düşük gümrük vergileriyle iç pazarlara dağıtılan kalitesiz mallar halkın fakirleşmesine ve hatta bir kısmının açlıktan ölmesine sebep olmuştur.

İki devletin İran'da kurmuş oldukları bankalar vasıtasıyla idareyi ağır borç yükü altına sokmalarından sonra baskıyı arttırmaları, tamamıyla Kaçar idaresinin acizliğinden kaynaklanmıştır. Her iki devletin bankalarından aldığ 1 borcu ödeyemez duruma gelen hükümet, kendi otoritesi üzerinde kurulan Duyun-1 Umumiye idaresinin istediklerini yapmaya başlamıştır. Mali olarak bir çıkmazın içerisine sürüklenen idare, İran'ın bütün yeraltı ve yerüstü kaynaklarını imtiyaz olarak vermekten çekinmemiştir. Bu süreçte İran halkının menfaatleri gözetilmemiş, Avrupa seyahatleri daha önemli görülmüştür.

\section{Kaynaklar}

Abdullayev, Z. Z. (1963). Promyshlennost zarozhdenie rabochego klâssa Irana v kontse XIXnachale $X X$, Bakû

Ademiyet, F. (1362). Emir-i Kebir ve Iran, Tehran.

Alem, M. (1371). Neft, Kudret ve Usul. Çev. Gulam Hüseyin Salihzade, Tehran.

Avery, P. (1363). Tarih-i Muasır-i İran. Çev. Refi Mihrabadi, Tehran.

Bakhash, S. (1984). “Abtracta Iranica, Iran: Monarchy and Reform Under The Qajars," Supple IV, Leiden.

Bosworth, G. E. (1977). Iran and İslam. Edinburgh.

Browne, E. (1351). Nameha-i ez Tebriz. Çev. Hasan Cevadi, Tehran.

Cemalzade, M. A. (1335). Genc-i Şayegan ya Evza-i İktisad-i Iran. Berlin.

Curzon, G. N. (1349). Iran ve Kaziye-i Iran. Çev. Vahid Mazenderani, Tehran.

Danişpur, Y. (1326). Bank-i Şahinşahi ve Imtiyaz. Tehran.

Dehgan, İ. (1330). Tarih-i Erak. Tehran.

Denis, W. (1977). The English Amongst the Persians During the Qajar Period, 1787-1921, London.

Devletabadi, Yahya (1330). Tarih-i Muasir ya Hayat-i Yahya I. Tehran.

Dihgan, İ. (1330). Tarih-i Erak, Tehran.

Entner, M. (1351). Revabit-i Bazargani-i Iran ve Rusya 1828-1914. Çev. Ataullah Nuriyan, Tehran.

Eşref, A. (1359). Rüşd-i Sermayedari der Iran: Devre-i Kacariye. Tehran.

Fahrai, İ. (1352). Gilan der Cenbeş-i Meşrutiyet. Tehran

Fatih, M. (1335). Pencah Sal Neft-i Iran. Tehran.

Ferahmend, A. (1387). "Gozeri-i Ber İmtiyazat Peyder Pey İngiliz Der Ahd-1 Nasiri," Fasılnâme-i Der Mütalât-ı Tarihi, Şomare: 22, s. 115-129.

Feuvrier. (1326). Se Sal Derbar-i İran. Çev. Abbas İkbal, Tehran.

Firuz K. (1354). Rus ve Ingiliz der Iran (terc. Menuçehr Emiri), Tehran.

Franklin, W. (1358). Sefername-i William Franklin (terc. Muhsin Cavidan), Tehran.

Greaves, R. (1959). Persia and the Defence of India. London.

Grothe, H. (1369). Sefername-i Grothe (terc. Mecid Celilvend), Tehran.

Gürgani, F. (1365). Iran der Meyan-ı Dö Seng-i Asya, Tehran.

Brughes, H. (1367). Sefer-i be Derbar-1 Sahibkurran (terc. M. Kürdbeççe), Tehran.

Hacı Seyyah, (1346). Hatırat-ı Hacı Seyyah (tash. Hamid Seyyah), Tehran

Hidayet, M. K. (1333). Guzareş. Tehran.

Hurmuci, M. C. (1363). Hakayikül'l Ahbari Nasiri. Tehran.

Issawi, C. (1971). The Economic History of Iran, 1800-1914. Chicago. 
İbrahim Bey, (1355). Sefername-i Esterabad ve Mazenderan ve Gilan (tash. Mesud Gülzari), Tehran.

De Morgan, J. (1338). Heyet-i Ilmi-i Fransa der Iran (terc. Kazım Vedii), Tebriz.

Kadıyani, A. (1376). Ferheng-i Fişerde Tarih-i IranHata! Yer işareti tanımlanmamış. ez A Ăaz ta Payan-ı Kacariye, Tehran.

Karadeniz, Y. (2006). Iran'da sömürgecilik mücadelesi ve Kaçar hanedanı (1795-1925), İstanbul.

Karadeniz, Y. (2012). Iran tarihi, İstanbul.

Karadeniz, Y. (2017). Islahat görünümlü ingiliz işgalinin safhaları, Ankara.

Karadeniz, Y. (2017). "1907'deki İngiliz-Rus anlaşması'nın İran siyasetine etkisi, "Route

Educational and Social Science Journal, Volume: 4/2, March 2017, s. 222-236.

Kazımzade, F. (1354). Rus ve Ingiliz der İan. Çev. Menuçehr Emiri, Tehran.

Keddie N. R. (1381). Iran Devran-ı Kacar ve ber Ameden-i Rıza Han, Çev. Mehdi

Hakikathah, Tehran.

Keddie, N. R. (1356). Tahrim-i Tenbaku der İran. Çev. Şahruh Kaimakami, Tehran.

Keyanfer, A. (1363). Keşf-i Telbis ya Do Ruyi ve Nireng-i İngiliz. Tash. Pervin İstahri, Tehran.

Kulakina, L. Michaelovna (1359). Istila-yı Emperyalizm ber Iran ve Tebdil-i in Kişver be Nime-i Müstemire. Çev. Sirus İzedi, Tehran.

Lambton, A. K. S. (1375). İran Asr-ı Kacar. Çev. Simin Fasihi, Meşhed.

Lanezowsky, G. (1353). Rekabet-i Rusya ve garb der Iran. Çev. İsmail Rain, Tehran.

Lesueur, E. (1368). Nüfuz-u İngiliziha der Iran (terc. Muhammed Bakır Ahmedi Terşizi), Tehran.

Markham, C. R. (1364). Tarih-i Iran der Devre-i Kacar. Çev. Mirza Rahim Ferzane, Losangeles.

Mehdevi, A. H. (1379). Tarih-i Revabit-i Harici-i Iran. Tehran.

Mekki, H. (1369). Mirza Taki Han Emir-i Kebir, Tehran 1369.

Merağayi, H. Z. (1344). Seyehatname-i İbrahim Bey, Tehran.

Mir Ahmedi, M. (1363). "Nüfuz-i İktisadi ve Siyasi-i Alman der İran," Mecelle-i Danişekde-i Edebiyat ve Ulum-i İnsani III, Daneşgah-1 Firdevsi, Meşhed.

Mohdevi, A. H. (1379). Tarih-i Revabit-i Harici-i Iran, Tehran.

Mostevfi, A. (1371). Şerh-i Zendegânî-i Men ya Tarih-i İçtimai ve İdari-yi Devre-i Kacariye, Tehran.

Muhammed Hasan Han, (1291). Salname-i Devlet-i Aliye-i Iran, Tehran.

Nasir, S. T. (1363). Iran der Berhord-i ba-isti 'mârgiran. Tehran.

Nevai, A. (1372). "Mehd-1 Ulya Cihan hanım," Tarih-i Muasır-ı Iran V, Tehran.

Nikitine, B. (1326). Hatırat ve sefername. Çev. Ali Muhammed Ferevşi, Tehran.

Robino, (1350). Vilayat-ı Darülmerzi-i Gilan (terc. Cafer Hamamizade), Tehran.

Ruşen, M. (1352). Vekayi-i Ferec. Reşt.

Safai, İ. (1352). Ayine-i tarih, Tehran.

Safevi, R. (1308). Ikktisad-i İan. Tehran.

Sipihr, M. T. (1273). Nasihü't-tevarih I-II. Tehran.

Stuart, C. (1854). Journal of a Residence in Northern Persia and the Adjecent Provinces of Turkey. London.

Sudager, M. R. (1342). Rüşd-i Sermayedaran der Iran. Tehran.

Şirazi, F. H. (1312). Asar-i Acem. Bombay.

Timuri, İ. (1332). Asr-i Bihaberi ya Tarih-i imtiyazat der Iran. Tehran.

Vekili, R.(1345). Tarih-i Irak-i Acem, Ferheng-i Iran-ı Zemin II. Tehran.

Wilson, A. (1928). The Persian Golf, London. 
Wright, D. (1977). The English Amongst the Persians During the Qajar Period, 1787-1921. London.

Wright, D. (1361). Nakşs-ı Ingiliz der IranHata! Yer işareti tanımlanmamış. (terc. Feramurz Feramurzi), Tehran. 